UDC $577+576$

\title{
Fibroblasts modulate the tumor cell motility and their mTOR/S6K1 phosphorylation status in vitro
}

\author{
N. Ya. Hotsuliak, V. V. Kosach, I. O. Tykhonkova, S. S. Palchevskii, A. I. Khoruzhenko \\ Institute of Molecular Biology and Genetics, NAS of Ukraine \\ 150, Akademika Zabolotnoho Str., Kyiv, Ukraine, 03143 \\ a.i.khoruzhenko@imbg.org.ua
}

\begin{abstract}
Aim. To determine the paracrine effect of cultured fibroblasts on HeLa cell motility and mTOR/ S6K1 phosphorylation status in vitro. Background. High cancer cell motility is a feature of the malignant tumor. The mTOR/S6K1 signaling network is one of the key links in regulation of cell migration. The cancer cell motility is also dependent on the tumor microenvironment but the effect of stroma on cancer cell migration is insufficiently studied. Methods. Cell culture, Western blot analysis, scratch test, statistical analysis. Results. Application of the media conditioned by a highly confluent monolayer culture of primer human dermal fibroblasts or NIH $3 \mathrm{~T} 3$ fibroblasts leads to a significant increase of the mTOR and S6K1 phosphorylation in HeLa cells. These conditioned media also have an inhibitory effect on the motility of tumor cells similar to that of mTOR/S6K1 signaling inhibitor rapamycin. Moreover, the combination of rapamycin and fibroblast-conditioned medium does not additionally change the cancer cell motility in comparison to rapamycin or fibroblast conditioned medium alone. Conclusion. The tumor microenvironment can significantly modulate the behavior of cancer cells and the efficiency of anticancer drugs. This should be taken into consideration when developing anticancer drugs.
\end{abstract}

Ke y w or d s: mTOR/S6K1 signaling network, tumormicroenvironment, fibroblasts, cancer cell migration, HeLa cell line

\section{Introduction}

The hypothesis that cancer is the result of disruption of normal tissue homeostasis along with genetic and epigenetic changes in epithelial cells has been established in modern oncology. The critical role of stromal microenviron- ment in the regulation of the processes of survival and proliferation of cancer cells, metabolic and physiological activity, invasion, angiogenesis, secondary tumor formation etc. has been previously demonstrated in numerous

(C) 2019 N. Ya. Hotsuliak et al.; Published by the Institute of Molecular Biology and Genetics, NAS of Ukraine on behalf of Biopolymers and Cell. This is an Open Access article distributed under the terms of the Creative Commons Attribution License (http://creativecommons.org/licenses/by/4.0/), which permits unrestricted reuse, distribution, and reproduction in any medium, provided the original work is properly cited 
studies $[1,2]$. In course of cancer development, the stromal compartment evolves and changes its functions from anti-oncogenic to supportive [3]. Moreover, the stromal cells are able to increase significantly the viability of cancer cells and their resistance to chemotherapy and radiotherapy. Therefore, the mutual interaction of stromal and tumor cells has been recently intensively investigated [4-7]. In particular, the effect of cancer-associated fibroblasts (CAFs) on the behavior of tumor cells has been investigated in different tumor types $[8,9]$. Thus, on one hand it was shown that exosomal miR-139 derived from gastric CAFs could inhibit the progression and metastasis of gastric cancer by decreasing MMP11 in tumor microspace [10]. On the other hand, it has been found that in breast cancer, CAFs constitute a supporting niche for the acquisition of cancer drug resistance [11]. Fibroblasts are known to produce a number of factors, including ECM proteins, enzymes, chemokines, growth factors and other downstream effectors, which in different ways, sometimes opposite, affect the expression of tumorigenic potential of cancer cells [12]. That is why, several approaches have been developed to study the modulating effect of stroma on tumor cells using the in vitro models: the first is the study of the effect of factors that can be produced by fibroblasts (a number of chemokines, growth factors, extracellular matrix components etc.), the second is the application of medium conditioned by fibroblasts [13] and the third is the co-cultivation of fibroblasts and tumor cells [14]. In the first case, the experimental conditions are controlled, but they are only partially similar to the conditions of the organism. In the second and third approaches, the experimental condi- tions are regarded as closer to the organism, but true quantitative and qualitative composition of the factors produced by the fibroblasts remains not fully known and uncontrolled. In these cases, it is difficult to point to one definitive factor that influenced the behavior of the tumor cells.

It is known that the signal transduction from extracellular agents inside a cell is mediated by the intracellular signaling networks. One of the signaling cascades, the function of which significantly altered in tumor cells, is the mTOR/S6K1 signaling pathway [15]. The central links of this signaling cascade are the mTOR and S6K1 kinases. Kinase mTOR (mammalian target of rapamycin) is one of the crucial regulatory element involved in multitude of intracellular events including protein biosynthesis, cell growth, proliferation etc. mTOR is a serine-threonine protein kinase, the activity of which is controlled by PI3K (phosphatidylinositol-3-kinase), AKT (protein kinase B), PTEN (Phosphatase and tensin homolog), tuberous sclerosis complexes (TSCs) 1 and 2. There are two mTOR functional complexes known as mTORC1 and mTORC2, which regulate different cellular events. mTORC1 fulfills a regulation of cell growth, proliferation, as well as a control of protein synthesis, etc. It is an important negative regulator of the autophagy, required also for the ribosome biogenesis. mTORC2 is involved in the regulation of architecture and polarity of the actin cytoskeleton and phosphorylation of AKT in mammalian cells [16]. The ribosomal protein S6 kinase 1 (S6K1) is a serine/threonine kinase of the AGC family and one of the main effectors of mTOR kinase. The gene S6K1 encodes three protein isoforms gener- 
ated by alternative splicing and alternates the ATG start site: a larger $85 \mathrm{kDa}$ S6K1 isoform (p85-S6K1) which contains nuclear localization sequence, the most extensively studied $70 \mathrm{kDa}$ S6K1 isoform (p70-S6K1) and recently identified $60 \mathrm{kDa}$ S6K1 isoform (p60$\mathrm{S} 6 \mathrm{~K} 1)$. The forth isoform $\mathrm{p} 31-\mathrm{S} 6 \mathrm{~K} 1 \mathrm{has}$ been characterized as a truncated type of the protein due to alternative splicing and lacks most of the kinase domain. The S6K1 activation absolutely requires the mTOR-mediated phosphorylation, and a specific mTOR-inhibitor rapamycin potently blocks S6K1 activation by all known agonists. The S6K1 activation is due to the phosphorylation of four serine residues on the C-terminal domain: Ser411, Ser418, Ser421, and Ser424. This process leads to the opening of an internal region of the protein, allowing mTOR to phosphorylate Threonine-389 (in p70-S6K1) or corresponding Threonine-412 (in p85-S6K1) [18]. Through mTOR, S6K1 accepts a wide range of upstream signals mediated by growth factors, mitogens, cytokines, amino acids, energy and cell stress. These signals are converted by S6K1 in the regulation of protein synthesis, ribosome biogenesis, transcription, mRNA splicing, metabolism, survival and apoptosis, cytoskeleton organization, cell proliferation and motility. The aberrant mTOR/S6K1 signaling is associated with various diseases, including cancer [17]. However, comprehension of molecular mechanisms how S6K1 signaling contributes to many of these pathological and physiological states and the real role of different S6K1 isoforms remains limited and requires future elucidation.

Therefore, the effect of fibroblast conditioned media on the activity (phosphorylation status) of S6K1 and mTOR kinases in HeLa cells was investigated in the presented work. It was revealed the activating effect of dermal fibroblasts and fibroblasts of NIH 3 T3 line on the phosphorylation level of indicated kinases. The dependence of cancer cell motility on the mTOR/S6K1 signaling has been previously identified [19]. Also, numerous studies point out a regulatory role of tumor microenvironment in the migration activity of tumor cells [20]. So, in the present study we investigated the effect of fibroblast conditioned media on the activity of mTOR/ S6K1 signaling and motility of HeLa cells in vitro.

\section{Materials and Methods}

\section{Cell culture}

HeLa cells and NIH 3 T3 fibroblasts were cultured in DMEM medium (Sigma) supplemented with $10 \% \mathrm{FBS}, 4 \mathrm{mM}$ glutamine, $50 \mathrm{U} / \mathrm{ml}$ penicillin and $50 \mu \mathrm{g} / \mathrm{ml}$ streptomycin at $37^{\circ} \mathrm{C}$ in $5 \% \mathrm{CO}_{2}$ in humidified atmosphere. Human dermal fibroblast cultures were obtained as it was described in [21]. Briefly, specimen of skin was cut in sterile conditions to obtain pieces about $1 \times 1 \times 1 \mathrm{~mm}$. Five pieces were put in Petri dish precoated with $1 \%$ gelatin and cultivated for 10 days in F-12 medium with $10 \%$ fetal bovine serum, 50 units $/ \mathrm{ml}$ penicillin, $50 \mu \mathrm{g} / \mathrm{ml}$ streptomycin, $4 \mathrm{mM}$ glutamine. After active fibroblast migration they were subcultivated. Monolayer fibroblasts and cancer cells cultures were applied for this study. Media conditioned by fibroblasts were obtained after $24 \mathrm{~h}$ of cultivation of confluent monolayer of NIH $3 \mathrm{~T} 3$ or human dermal fibroblasts. 


\section{Scratch assay}

HeLa cells were cultured for $72 \mathrm{~h}$ before scraping in 6 well plate. Subconfluent cell monolayer was scrapped by tip to create an experimental wound. Nonadhered cells were removed by aspiration. Medium supplemented with $10 \mu \mathrm{M}$ rapamycin, or $20 \%$ conditioned media, or their combination was added into corresponding wells. The images of randomized fields of observation of each scratch were captured just after scraping and after 24 hours of cultivation. The width of experimental wound was determined from these images using Icy software [22].

\section{Western blot analysis}

Cells were washed with ice-cold PBS and were lysed on ice for $30 \mathrm{~min}$ in $20 \mathrm{mM}$ Tris- $\mathrm{HCl}$, $\mathrm{pH}$ 7.5, $150 \mathrm{mM} \mathrm{NaCl}, 1 \mathrm{mM}$ EDTA, $1 \mathrm{mM}$ EGTA, $0.5 \%$ Triton X-100, supplemented with a Complete EDTA free protease inhibitor cocktail tablet (Roche). Whole-cell lysates were centrifuged at $12,000 \mathrm{~g}$ for $15 \mathrm{~min}$ at $+4{ }^{\circ} \mathrm{C}$, and the supernatant was collected. The protein concentrations were determined using Bradford assay. Equal amounts of protein were resolved on $10 \%$ SDS-PAGE and electrotransferred onto polyvinylidene difluoride (PVDF) membranes for immunoblotting. The following antibodies were used in immunodetection: anti-phospho-mTOR (Ser2448) (Cell Signalling, catalogue No.5536), anti-phosphop70 S6 Kinase (Thr389) (Cell Signalling, catalogue No. 9234), anti- $\beta$-actin (SigmaAldrich, A5441), anti-FRAP (N-19) (Santa Cruz Biotechnology, catalogue No. sc-1549, anti-C-terminal S6 Kinase [23], anti-Rabbit and anti-Mouse antibodies (Jackson ImmunoResearch). Antibodies were applied in dilutions and immunoblotting conditions recommended in specifications.

\section{Statistical Analysis}

The data were analyzed by using Student's $T$ test. The results were expressed as the mean $\pm \mathrm{SD}$. The differences were considered significant at $p<0.05$. Each experiment was repeated at least 3 times.

\section{Results and Discussion}

To evaluate the effect of fibroblast-derived factors on $\mathrm{mTOR} / \mathrm{S} 6 \mathrm{~K} 1$ signaling in cancer cells, for the beginning the content of mTOR and S6K1 kinases at the protein level in cultured HeLa cells was assayed by Western blot analysis under the influence of rapamycin, human dermal fibroblast conditioned medium, NIH 3T3 fibroblast conditioned medium and combination of rapamycin with corresponding conditioned medium (Fig. 1).

As expected, no statistically significant difference between mTOR and S6K1 expression levels was detected. Therefore, rapamycin and media conditioned by dermal fibroblasts or NIH 3 T3 cells did not cause changes in mTOR and S6K1 protein amounts.

On the other hand, it was revealed that the paracrine factors produced by dermal fibroblasts and NIH $3 \mathrm{~T} 3$ fibroblasts caused a significant increase in the phosphorylation of these kinases. Earlier it was shown that mTOR kinase has the main four phosphorylation sites - namely: Ser1261 localized at the HEAT domain and three other sites Thr2446, Ser2448, Ser2481 - at regulatory domain, which is important for the mTOR kinase activity. The most studied is Serine2448, which is an indicator of activation of mTOR kinase by S6K1 [24]. As 

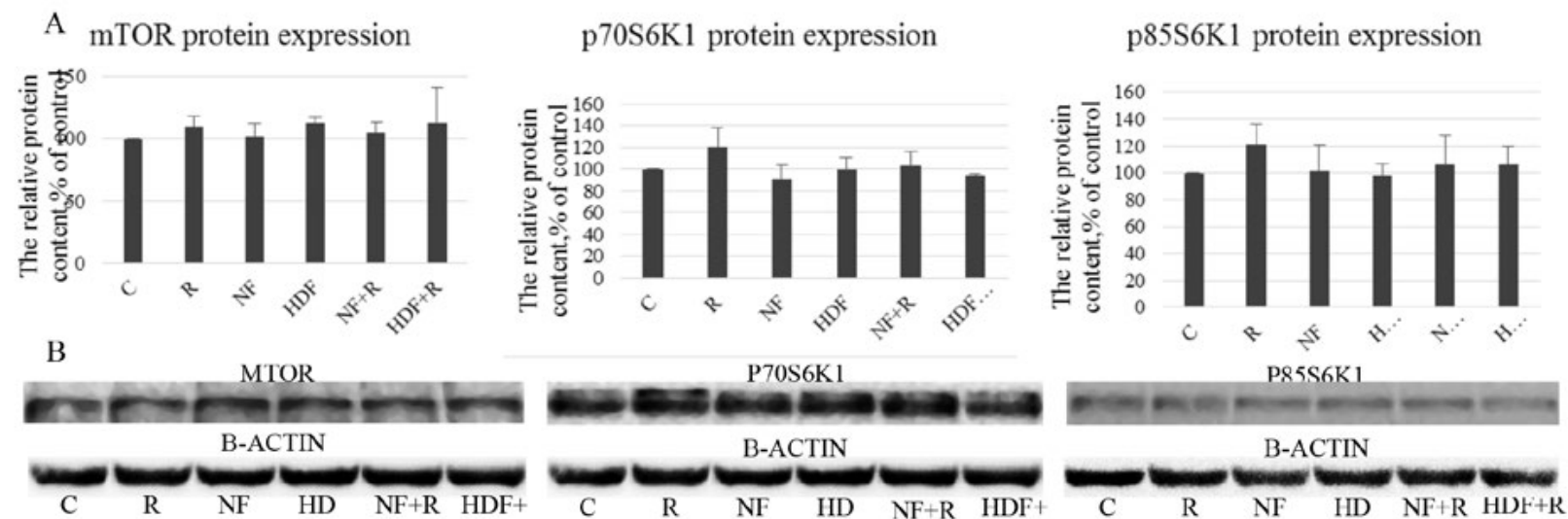

Fig. 1. Western blot detection of protein content of mTOR, p70-S6K1 and p85-S6K1 in HeLa cells under the influence of rapamycin, human dermal fibroblast conditioned medium, NIH 3T3 fibroblast conditioned medium and combination of rapamycin with corresponding conditioned medium. A - Densitometric analysis results are expressed as \% of control. $B$ - Western Blot analysis of mTOR, p70S6K1 and p85S6K1 content was performed in experimental conditions: $\mathrm{C}$ - control HeLa cells cultured in standard conditions, $\mathrm{R}$ - treatment with $10(\mathrm{nM})$ rapamycin, NF- treatment with $20 \%$ medium conditioned by NIH 3 T3 fibroblasts, HDF - treatment with $20 \%$ medium conditioned by human dermal fibroblasts, $\mathrm{NF}+\mathrm{R}$ - treatment with $20 \%$ medium conditioned by NIH $3 \mathrm{~T} 3$ fibroblasts and $10 \mathrm{nM}$ rapamycin, $\mathrm{HDF}+\mathrm{R}$ - treatment with $20 \%$ medium conditioned by human dermal fibroblasts and $10(\mathrm{nM})$ rapamycin.

expected, rapamycin had an inhibitory effect on the mTOR phosphorylation at this site (Fig. 2). Our studies revealed a statistically significant increase of the phosphorylation of mTOR kinase at Ser2448 under the influence of the NIH 3T3 fibroblasts conditioned medium. Moreover, the combination of rapamycin with the NIH 3T3 fibroblasts conditioned medium reduced mTOR phosphorylation almost to the control level. The effect of paracrine factors produced by human dermal fibroblasts was similar but much less pronounced (Fig. 2).

An important indicator of the mTOR/S6K1 signaling activation is the phosphorylation of S6K1 at Thr389/412. The kinase phosphorylation at this site is carried out by the mTOR kinase [25]. We observed considerable statistically significant increases in phosphorylation of p70-S6K1 isoform under the influence of medium conditioned by dermal fibroblasts, which exceeded more than $200 \%$ of the control level. The effect of NIH3T3 fibroblasts media exceeded $250 \%$ of the control level of S6K1 phosphorylation. The addition of rapamycin only slightly reduced the effect of conditioned media, in these cases the level of phosphorylation was about $170 \%$ of the control sample (Fig. 2).

A significant increase of phosphorylation under the influence of fibroblasts was also observed for the p85-S6K1 isoform (Fig. 2). As before, rapamycin reduced the effect of conditioned media, but did not return the phosphorylation degree of p85-S6K1 to the level detected in control cells.

One of the important distinguishing characteristics of tumor cells is the ability to move actively [26]. The involvement of mTOR/ 



Fig. 2. Westren Blot analysis of phosphorylation status of mTOR, p70-S6K1 and p85-S6K1 in HeLa cells after $24 \mathrm{~h}$ treatment with rapamycin, human dermal fibroblast conditioned medium, NIH 3 T3 conditioned medium and combination of rapamycin with corresponding conditioned medium. A - Densitometric analysis results are expressed as \% of control. $B$ - Western Blot analysis of phosphorylation status of mTOR (Ser2448), p70-S6K1 (Thr389) and p85-S6K1 (Thr412) at applied experimental conditions: $\mathrm{C}$ - control HeLa cells cultured in standard conditions, $\mathrm{R}$ - treatment with $10(\mathrm{nM})$ rapamycin, NF- treatment with $20 \%$ medium conditioned by NIH 3 T3 fibroblasts, HDF - treatment with $20 \%$ medium conditioned by human dermal fibroblasts, NF+R - treatment with $20 \%$ medium conditioned by NIH 3 T3 fibroblasts and $(\mathrm{nM})$ rapamycin, $\mathrm{HDF}+\mathrm{R}$ - treatment with $20 \%$ medium conditioned by human dermal fibroblasts and (nM) rapamycin. Results were regarded as statistically significant $\left({ }^{*}-p<0.05\right.$; $\left.{ }^{*}-p<0.01\right)$ using Student's $t$ test.

S6K1 signaling cascade in the regulation of cell migration activity has been previously reported [27]. Therefore, we analyzed the locomotor capacity of HeLa cells under the influence of fibroblast conditioned media and under the inhibition of $\mathrm{mTOR} / \mathrm{S} 6 \mathrm{~K} 1$ signaling in tumor cells. Usually for conditioning medium the fibroblast culture in log phase is applied, such cells are characterized by high proliferative index. Under these conditions, the activating effect of fibroblasts on the locomotor properties of tumor cells is often observed. In our opinion, under the condition of organism in fibroblasts, including CAFs, a synthetic pro- cess prevails over the proliferation, in comparison with the monolayer culture in log phase. Therefore, in our study the fibroblasts, which formed a highly confluent monolayer in stationary phase of growth, were used for conditioning the medium. We assume that in this state the cells divide less actively, but the level of their extracellular matrix production is higher than in actively proliferating fibroblasts. In our opinion, such experimental conditions are closer to those existing in the organism. In such a way the study of the paracrine effect of fibroblasts on tumor cell motility was performed, and it was revealed a significant mod- 
ulating effect on the tumor cell locomotion. Earlier it was observed that inhibition of the $\mathrm{mTOR} / \mathrm{S} 6 \mathrm{~K} 1$ signaling cascade leads to a decrease of tumor cell motility in vitro. Our data also indicate the inhibition of the locomotor function of tumor cells under the influence of rapamycin. An addition of media conditioned by primary cultures of human dermal fibroblasts and murine fibroblasts of NIH 3 T3 line, slowed down the rate of tumor cell migration (Fig. 3). Thus, according to our data, fibroblasts had a significant activating effect on the mTOR/S6K1 signaling, however, on the other

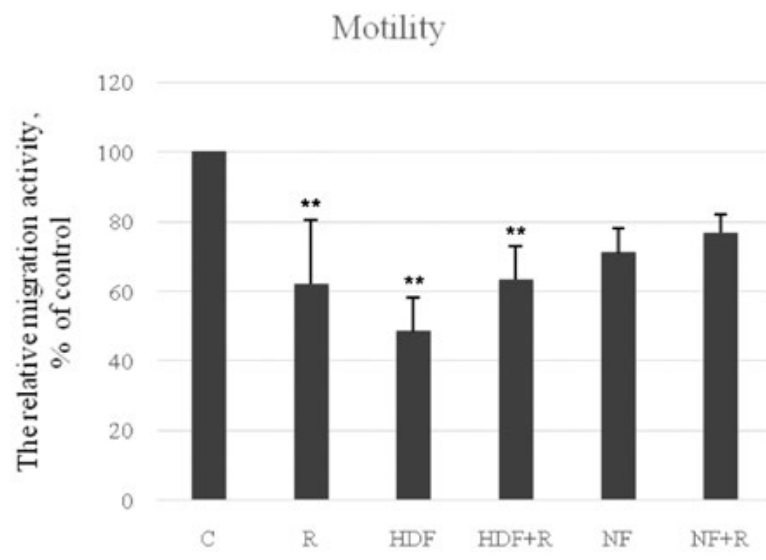

Fig. 3. Detection of locomotor properties of HeLa cells after $24 \mathrm{~h}$ treatment with rapamycin, human dermal fibroblast conditioned medium, NIH $3 \mathrm{~T} 3$ fibroblast conditioned medium and combination of rapamycin with corresponding conditioned medium in scratch test $(\mathrm{C}-$ control HeLa cells cultured in standard conditions, $\mathrm{R}$ - treatment with $10(\mathrm{nM})$ rapamycin, NF- treatment with $20 \%$ medium conditioned by NIH 3 T3 fibroblasts, HDF treatment with $20 \%$ medium conditioned by human dermal fibroblasts, NF+R - treatment with $20 \%$ medium conditioned by NIH $3 \mathrm{~T} 3$ fibroblasts and (nM) rapamycin, $\mathrm{HDF}+\mathrm{R}$ - treatment with $20 \%$ medium conditioned by human dermal fibroblasts and (nM) rapamycin). Results were regarded as statistically significant $(* *-p<0.01)$ using Student's $T$ test. hand, inhibited the migration ability of HeLa cells in vitro. Unlike intact cells, the cells cultured in the presence of medium conditioned by both NIH 3 T3 fibroblasts and dermal fibroblasts were insensitive to rapamycin. Namely, the migration velocity of HeLa cells in the presence of conditioned medium of fibroblasts or combination of conditioned media with rapamycin statistically did not differ (Fig. 3). So, the presence of the factors produced by fibroblasts in culture medium on one hand inhibited the cell migration, on the other hand abolished the inhibitory effect of rapamycin on tumor cell motility.

Fibroblasts produce a variety of growth factors, which are able to activate mTOR/S6K1 signaling as it was observed using Western Blot analysis. Usually, the activation of this signaling positively correlates with a high rate of cell migration. However, in our model an addition of fibroblast conditioned media to cancer cells caused an opposite effect. We suppose that quantitative and qualitative content of media conditioned by fibroblasts at subconfluent monolayer (as applied usually) and at highly confluent monolayer (as it was applied in this study) can be significantly different, and as a result the regulation of cancer cell motility can be implemented in different ways. For example, different growth factors secreted by fibroblasts could be involved in such regulatory mechanism. The formation of focal adhesion complexes and state of FAK (focal adhesion kinase) are regarded as an index of the cell migration activity. It was observed that the focal adhesion formation could be modulated by the growth factors including IGF-I (insulinlike growth factor) produced by fibroblasts [28]. IGF-I binds to its receptor on the surface 
of cancer cells, and then, the signal can be transmitted into tumor cell in two ways. IGFR (IGF-I receptor) can interact with its substrate - IRS1 (IGF-I receptor substrate) and via PIP3 - PDK1 - AKT - Tuberous sclerosis complex - Rheb axis it can activate mTOR and S6K1. Also, IGFR can initiate signal transduction through another branch, namely via Grb2 (Growth factor receptor-bound protein 2) - SOS (Son of Sevenless, guanine nucleotide exchange factors) it can activate Ras. The activated Ras decreases the quantity of focal adhesions. Because the migration ratio is dependent on the dynamics of Ras and integrin signaling, the level of Ras activation can define the migratory potential of tumor cells [29]. Hence, the behavior on a whole and the migration potential of tumor cells in particular significantly depend on the tumor microenvironment.

So, in the presented work we have shown that the factors produced by a highly confluent monolayer of fibroblasts induce an elevation of [the] mTOR and S6K1 kinases phosphorylation level in HeLa cells. Also, we registered a similar decrease in the migration activity of mentioned tumor cells in scratch test in the presence of rapamycin, fibroblast conditioned medium and their combination. The obtained results pointed out the necessity to take the tumor microenvironment into consideration when developing anticancer drug.

\section{REFERENCES}

1. Mishra R, Haldar S, Suchanti S, Bhowmick NA. Epigenetic changes in fibroblasts drive cancer metabolism and differentiation. Endocr Relat Cancer. 2019. pii: ERC-19-0347.R1.
2. McMillin DW, Negri JM, Mitsiades CS. The role of tumour-stromal interactions in modifying drug response: challenges and opportunities. Nat Rev Drug Discov. 2013;12(3):217-28.

3. Pietras $K$, Ostman A. Hallmarks of cancer: interactions with the tumor stroma. Exp Cell Res. 2010;316(8):1324-31.

4. Ilie MD, Vasiljevic A, Raverot $G$, Bertolino P. The Microenvironment of Pituitary Tumors-Biological and Therapeutic Implications. Cancers (Basel). 2019;11(10). pii: E1605.

5. Urdal J, Waldeland JO, Evje S. Enhanced cancer cell invasion caused by fibroblasts when fluid flow is present. Biomech Model Mechanobiol. 2019;18(4):1047-1078.

6. Dourado MR, Korvala J, Åström P, De Oliveira CE, Cervigne NK, Mofatto LS, Campanella Bastos D, Pereira Messetti AC, Graner E, Paes Leme AF, Coletta $R D$, Salo $T$. Extracellular vesicles derived from cancer-associated fibroblasts induce the migration and invasion of oral squamous cell carcinoma. $J$ Extracell Vesicles. 2019;8(1):1578525.

7. Goulet CR, Champagne A, Bernard G, Vandal D, Chabaud S, Pouliot F, Bolduc S. Cancer-associated fibroblasts induce epithelial-mesenchymal transition of bladder cancer cells through paracrine IL-6 signalling. BMC Cancer. 2019;19(1):137.

8. Liu CL, Pan HW, Torng PL, Fan MH, Mao TL. SRPX and HMCN1 regulate cancer-associated fibroblasts to promote the invasiveness of ovarian carcinoma. Oncol Rep. 2019;42(6):2706-2715.

9. Han Q, Huang B, Huang Z, Cai J, Gong L, Zhang Y, Jiang $J$, Dong $W$, Wang $Z$. Tumor cell-fibroblast heterotypic aggregates in malignant ascites of patients with ovarian cancer. Int J Mol Med. 2019;44(6):2245-2255.

10. Xu G, Zhang B, Ye J, Cao S, Shi J, Zhao Y, Wang Y, Sang J, Yao Y, Guan W, Tao J, Feng M, Zhang $W$. Exosomal miRNA-139 in cancer-associated fibroblasts inhibits gastric cancer progression by repressing MMP11 expression. Int J Biol Sci. 2019;15(11): 2320-2329.

11. Li X, Li Q, Yu X, Li H, Huang G. Reverse of microtubule-directed chemotherapeutic drugs resistance induced by cancer-associated fibroblasts in breast cancer. Onco Targets Ther. 2019;12:7963-7973. 
12. Liu T, Zhou L, Li D, Andl T, Zhang Y. CancerAssociated Fibroblasts Build and Secure the Tumor Microenvironment. Front Cell Dev Biol. 2019;7:60.

13. Zhang X, Hwang YS. Cancer-associated fibroblast stimulates cancer cell invasion in an interleukin-1 receptor (IL-1R)-dependent manner. Oncol Lett. 2019;18(5):4645-4650.

14. Yakavets I, Jenard S, Francois A, Maklygina Y, Loschenov V, Lassalle HP, Dolivet G, Bezdetnaya L. Stroma-Rich Co-Culture Multicellular Tumor Spheroids as a Tool for Photoactive Drugs Screening. $J$ Clin Med. 2019;8(10). pii: E1686.

15. Filonenko $V V$. PI3K/mTOR/S6K signaling pathway - new players and new functional links. Biopolym Cell. 2013;29(3):207-14.

16. Watanabe R, Wei L, Huang J. mTOR signaling, function, novel inhibitors, and therapeutic targets. J Nucl Med. 2011;52(4):497-500.

17. Magnuson B, Ekim B, Fingar DC. Regulation and function of ribosomal protein S6 kinase (S6K) within mTOR signalling networks. Biochem J. 2012; 441(1):1-21.

18. Burnett PE, Barrow RK, Cohen NA, Snyder SH, Sabatini DM. RAFT1 phosphorylation of the translational regulators p70 S6 kinase and 4E-BP1. Proc Natl Acad Sci U S A. 1998;95(4):1432-7.

19. Kosach V, Shkarina K, Kravchenko A, Tereshchenko Y, Kovalchuk E, Skoroda L, Krotevych M, Khoruzhenko $A$. Nucleocytoplasmic distribution of S6K1 depends on the density and motility of MCF-7 cells in vitro. Version 2. F1000Res. 2018 [revised 2018];7:1332.

20. Alkasalias T, Moyano-Galceran L, Arsenian-Henriksson M, Lehti K. Fibroblasts in the Tumor Microenvironment: Shield or Spear? Int J Mol Sci. 2018;19(5). pii: E1532.

21. Nizheradze $K A$. Binding of wheat germ agglutinin to extracellular network produced by cultured human fibroblasts. Folia Histochem Cytobiol. 2000;38(4):167-73.

22. de Chaumont F, Dallongeville S, Chenouard N, Hervé N, Pop S, Provoost T, Meas-Yedid V, Pankajakshan P, Lecomte T, Le Montagner Y, Lagache T, Dufour A, Olivo-Marin JC. Icy: an open bioimage informatics platform for extended reproducible research. Nat Methods. 2012;9(7):690-6.

23. Savinska LO, Kijamova RG, Pogrebnoy PV, Ovcharenko GV, Gout IT, Filonenko VV. Comparative characteri-zation of S6 kinase $\alpha$ and $\beta$ isoforms expression in mammalian tissues. Biopolym Cell. 2001; 17(5):374-9

24. Chiang GG, Abraham RT. Phosphorylation of mammalian target of rapamycin (mTOR) at Ser-2448 is mediated by p70S6 kinase. $J$ Biol Chem. 2005; 280(27):25485-90.

25. Rosner M, Schipany K, Hengstschläger M. p70 S6K1 nuclear localization depends on its mTORmediated phosphorylation at T389, but not on its kinase activity towards S6. Amino Acids. 2012; 42(6):2251-6.

\section{Фібробласти модулюють рухливість пухлинних клітин статус фосфорилювання mTOR/S6K1 Ta in vitro}
Н. Я. Гоцуляк, В. Р. Косач, І. О. Тихонкова, С. С. Пальчевський, А. І. Хоруженко

Мета. Визначити паракринний вплив культивованих фібробластів на рухливість клітин HeLa та статус фосфорилювання mTOR / S6K1 цих пухлинних клітин in vitro. Передумови. Висока рухливість ракових клітин $\epsilon$ відмінною рисою злоякісної пухлини. Сигнальна мережа mTOR / S6K1 є однією з ключових ланок внутрішньоклітинного механізму регуляції міграції клітин. Крім того, рухливість ракових клітин залежить від мікрооточення пухлини, але шляхи впливу строми на міграцію ракових клітин слід вивчити детальніше. Методи. Культура клітин, Вестернт блотаналіз, тест «на подряпину» in vitro, статистичний аналіз. Результати: Застосуваннясередовищ, кондиційованих «супер конфлюентною» культурою первинних фібробластів людини або фібробластами лінії NIH3T3, призводить до значного підвищення рівня фосфорилювання кіназ mTOR i S6K1 у ракових клітинах лінії HeLa. Крім того, зазначені кондиціоновані середовища мають інгібуючу дію на міграторні властивості пухлинних клітин кількісно подібні до дії рапаміцину, інгібітора mTOR / S6K1сигнальної мережі. Більш того, комбінована обробка рапаміцином та кондиційованим фібро- 
бластами середовищем не змінює рухливості ракових клітин порівняно із застосуванням лише рапаміцину або кондиційованого фібробластами середовища. Висновок. Пухлинне мікрооточення може значно модулювати поведінку ракових клітин та ефективність протипухлинних препаратів. Це слід враховувати при розробці протиракових препаратів.

Кл юч о в і сл ов а: mTOR/S6K1 сигнальна мережа, пухлинне мікрооточення, фібробласти, міграція злоякісних клітин, пухлинні клітини лінії HeLa

\section{Фибробласты модулируют подвижность опухолевых клеток статус фосфорилирования mTOR/S6K1 и in vitro}
Н. Я. Гоцуляк, В. Р. Косач, И. А. Тихонкова, С. С. Пальчевский, А. И. Хоруженко

Цель. Определить паракринное влияние культивируемых фибробластов на подвижность клеток HeLa и статус фосфорилирования mTOR/S6K1 этих опухолевых клеток in vitro. Высокая подвижность ракових клеток является отличительной чертой злокачественной опухоли. Сигнальная сеть mTOR/S6K1 является одним из ключевых звеньев внутриклеточного механизма регуляции миграции клеток. Кроме того, подвижность ракових клеток зависит от микроокружения опухоли, но пути влияния стромы на миграцию ракових клеток следует изучить более детально. Методы.
Культура клеток, Вестернт блот анализ, тест «на царапину» in vitro, статистический анализ. Результаты. Применение сред, кондиционированных «супер конфлюентной» культурой первичных дермальных фибробластов человека или фібробластами линии NIH 3 Т3 приводит к значительному повышению уровня фосфорилирования киназ mTOR и S6K1 раковых клеток линии HeLa. Кроме того, указанные кондиционированные среды оказывают ингибирующее влияние на миграционные свойства опухолевых клеток, количественно сопоставимое с действием рапамицина, ингибитора mTOR/S6K1 сигнальной сети. Более того, комбинированная обработка рапамицином и кондиционированной фібробластами средой не изменяет подвижности раковыхклеток по сравнению с применением только рапамицина или кондиционированной фібробластами среды. Выводы. Опухолевое микроокружение может значительно модулировать поведение ракових клеток и эффективность противо-опухолевых препаратов. Это следует учитывать при разработке последних.

Кл юч е в ы е с л о в а: mTOR/S6K1 сигнальная сеть, опухолевое микроокружение, фибробласты, миграция злокачественных клеток, опухолевые клетки линии HeLa

Received 13.08.2019 